\title{
PELAKSANAAN PROGRAM UPAYA KHUSUS (UPSUS) SWASEMBADA PANGAN BERKELANJUTAN DI KABUPATEN KENDAL PROVINSI JAWA TENGAH
}

\section{IMPLEMENTATION OF SPECIAL EFFORTS PROGRAM OF SUSTAINALE FOOD SELF- SUFFiCIENCY IN KENDAL REGENCY CENTRAL JAVA PROVINCE}

\author{
${ }^{1)}$ Agus Dwi Nugroho, ${ }^{2)}$ Charisma Ummu F, ${ }^{3)}$ Ria Puji A, ${ }^{4}$ Lendy Vinte I, ${ }^{5)}$ Ceria Lestari, \\ ${ }^{6}$ Setiya Tri P, ${ }^{7)}$ Novi Anjarwati, ${ }^{8)}$ Andri Anjarwati, ${ }^{9}$ Ely Wisnu B, ${ }^{10}$ Dika Afif Prata \\ 1,2,4,5,6,7,8,9,10) Fakultas Pertanian Universitas Gadjah Mada \\ Jl. Flora Bulaksumur Yogyakarta \\ email : agus.dwi.n@mail.ugm.ac.id
}

\begin{abstract}
ABSTRAK
Kabupaten Kendal diharapkan mampu meningkatkan produksi untuk menunjang swasembada pangan. Untuk itu, diperlukan teknologi baru, baik input pertanian (pupuk, benih, pestisida dan lainnya) maupun sistem budidaya tanaman. Tujuan pengabdian masyarakat ini adalah 1) difusi teknologi pertanian UGM kepada petani dan 2) uji coba demplot dengan teknologi pertanian modern. Kegiatan pengabdian dilaksanakan pada April sampai Juli 2016 di Kecamatan Limbangan, Boja, Kangkung, Sukorejo dan Patean. Kelompok sasaran pada pengabdian ini adalah kelompok tani pada lima kecamatan tersebut. Hasil pendampingan program Upaya Khusus Swasembada Pangan menunjukkan kegiatan Rehabilitasi Jaringan Irigasi Tersier ada yang belum terlaksana, kegiatan bantuan benih bersubsidi telah terealisasi sesuai target, kegiatan tanam jajar legowo berjalan dengan baik. Aktvitas penyuluhan memberikan pengetahun baru bagi petani tentang teknologi usahatani (pertanian organik, pembuatan mikoriza dan sistem jajar legowo) dan petani menerapkan teknologi usahatani tersebut pada periode pendampingan. Beberapa masalah yang dihadapi dalam pelaksanaan UPSUS antara lain waktu pendampingan yang terlalu pendek serta pelaksanaan RJIT ada yang terlambat karena kelompok tani belum memperoleh dana dari pemerintah. Dalam rangka pengembangan UPSUS, sebaiknya waktu pendampingan dapat diperpanjang serta dinas juga perlu melakukan pengawasan agar program RJIT dapat dilaksanakan tepat waktu.
\end{abstract}

Kata Kunci : UPSUS, Swasembada Pangan, Penguatan Kelembagaan, Jajar Legowo, Demplot

\section{ABSTRACT}

Kendal Regency expected can increasing production to support food self-sufficiency. To increasing production, farmers need new technologies, both agricultural inputs as well as plant cultivation system. The purposes of this activity are 1) the diffusion of agricultural technology to farmers and 2) the demonstration plots of agricultural land with modern technology. The activity held on April until July 2016 in Limbangan, Boja, Kangkung, Sukorejo and Patean District. The target group in this activity is the farmer groups in that sub-district. The results of escorting UPSUS Program indicate that the Tertiary Irrigation Rehabilitation activity have not been implemented yet in some districts, the subsidized seed activity have been realized in accordance with the target, and the jajar legowo planting activity is running well. Extension activities able to provide new knowledge for farmers about some farming technologies (organic farming, mikoriza dan jajar legowo system) and farmers can apply it in the period of assistance. Some of the problems in UPSUS are the period of this activity too short and the implementation of RJIT is too late because the farmer groups 
Agus Dwi Nugroho, Charisma Ummu F, Ria Puji A, Lendy Vinte I, Ceria Lestari, Setiya Tri P, Novi Anjarwati, Andri Anjarwati, Ely Wisnu B, Dika Afif Prata

Pelaksanaan Program Upaya Khusus (UPSUS) Swasembada Pangan Berkelanjutan

Di Kabupaten Kendal Provinsi Jawa Tengah

have not received funds from the government. To development UPSUS, it is advisable that the period can be extended and the Department of Agriculture Kendal Regency also needs to supervise the RJIT program so it can be conducted on time.

Keyword : UPSUS, Food Self-Sufficiency, Jajar Legowo, Institutional Strengthening, Demplot

Submitted : 10 April 2018 Revision: 18 April 2018 Accepted : 25 Mei 2018

\section{PENDAHULUAN}

Pembangunan pertanian terus dilakukan pemerintah dalam rangka mencapai swasembada pangan. Namun upaya swasembada pangan juga menghadapi berbagai tantangan. Salah satunya laju konversi lahan terus meningkat, terutama di Pulau Jawa. Hasil Sensus Pertanian Tahun 2013 menunjukkan rata-rata kepemilikan lahan petani di Indonesia adalah 0,22 ha. Sedangkan realisasi perluasan lahan atau program cetak sawah dari tahun 2006-2013 hanya mencapai 273 ribu ha atau lebih rendah dari laju alih fungsi lahan pertanian ke non pertanian (Badan Pusat Statistik, 2013).

Berbagai permasalahan tersebut dapat diselesaikan dengan menggunakan pengenalan teknologi modern pertanian. Teknologi tersebut akan berdampak meningkatkan produksi pertanian, meningkatkan efisiensi usahatani dan pendapatan petani. Pengenalan teknologi pertanian modern inenjadi fokus dari pemerintahan Jokowi-JK melalui Upaya Khusus (UPSUS) swasembada pangan.

Program UPSUS dilaksanakan pada tahun 2015-2017 dengan melibatkan Kementerian Pertanian, TNI, dan Perguruan Tinggi. UPSUS swasembada pangan sendiri mencakup beberapa komoditas strategis yang menyangkut ketersediaan stok pangan dan stabilisasi inflasi nasional. Komoditas strategis yang termasuk dalam aktivitas UPSUS antara lain padi, jagung, kedelai, daging sapi, tebu, bawang merah dan cabai. Untuk mencapai swasembada pangan pemerintah merencanakan berbagai program dalam
UPSUS diantaranya Rehabilitasi Jaringan Irigasi Tersier (RJIT), penyediaan alat dan mesin pertanian (Alsintan), penyediaan dan penggunaan benih unggul, penyediaan dan penggunaan pupuk berimbang, pengaturan musim tanam dengan menggunakan Kalender Musim Tanam (KATAM), pelaksanaan Program Gerakan Penerapan Pengelolaan Tanaman Terpadu (GP-PTT), Perluasan Areal Tanam (PAT) jagung dan kedelai, Peningkatan optimasi lahan (POL) dan pengujian teknologi.

Salah satu perguruan tinggi yang bermitra dengan Kementerian Pertanian dalam program UPSUS Swasembada Pangan adalah Universitas Gadjah Mada dengan menerjunkan mahasiswa dan alumni untuk melaksanakan pendampingan kepada petani. Fakultas Pertanian UGM dilibatkan dengan wilayah binaan beberapa kabupaten di Provinsi Jawa Tengah dan Daerah Istimewa Yogyakarta. Salah satu kabupaten yang menjadi wilayah pendampingan adalah Kabupaten Kendal.

Petani padi di Kendal menghadapi berbagai permasalahan terkait budidaya tanaman pangan yaitu produktivitas yang masih rendah, harga faktor produksi (benih, pupuk, tenaga kerja dan pestisida) setiap tahun mengalami kenaikan dan harga produk yang berfluktuatif tidak menentu ketika panen (Darwanto, 2010). Oleh karena itu, diperlukan upaya peningkatan produktivitas lahan pertanian tanaman pangan sehingga kesejahteraan petani juga akan meningkat. 
Agus Dwi Nugroho, Charisma Ummu F, Ria Puji A, Lendy Vinte I, Ceria Lestari, Setiya Tri P, Novi Anjarwati, Andri Anjarwati, Ely Wisnu B, Dika Afif Prata Pelaksanaan Program Upaya Khusus (UPSUS) Swasembada Pangan Berkelanjutan

Di Kabupaten Kendal Provinsi Jawa Tengah

Tujuan dari aktivitas pengabdian masyarakat ini adalah 1) difusi teknologi pertanian UGM kepada petani, dan 2) uji coba demplot dengan teknologi pertanian modern.

\section{METODE KEGIATAN}

Aktivitas UPSUS swasembada pangan di Kabupaten Kendal dilaksanakan pada 18 April - 31 Juli 2016. Wilayah yang menjadi sasaran aktivitas ini antara lain Kecamatan Limbangan, Boja, Kangkung, Sukorejo dan Patean. Pemilihan wilayah binaan UPSUS oleh tim UGM berdasarkan masukan dari Dinas Pertanian, Peternakan Perkebunan dan Kehutanan (DP3K) Kabupaten Kendal. Kelompok sasaran pada pengabdian ini adalah kelompok tani pada lima kecamatan tersebut.

Aktivitas yang dilaksanakan selama kegiatan UPSUS mengarah kepada pendidikan masyarakat dan pelatihan yakni

1. Pendampingan pengawasan penyaluran bantuan program pemerintah terkait Rehabilitasi Jaringan Irigasi Tersier (RJIT), bantuan benih bersubsidi, dan pendampingan pola tanam jajar legowo.

2. Penguatan kelembagaan kelompok tani dengan kegiatan penyuluhan teknis budidaya dan teknologi pertanian.

3. Demplot/uji teknologi komoditas padi.

Lokasi demplot UGM ada di Desa Meteseh, Kecamatan Boja. Demplot dilaksanakan pada bulan Mei - Juli 2016 pada lahan seluas 0,25 ha. Adapun bahan dan alat yang dibutuhkan adalah

1. Bahan : benih padi varietas Ciherang, pupuk (kimia, organik, dan hayati), dan pestisida;

2. Alat : sprayer dan caplak (alat pengatur jarak tanam jajar legowo)
Rancangan perlakuan yang dilakukan adalah membagi lahan menjadi 2 petak dengan luasan dan varietas yang sama yaitu petak pertama dengan perlakuan kontrol (budidaya padi sesuai kebiasaan petani) dan petak kedua dengan perlakuan uji teknologi. Pola tanam pada demplot ini jajar legowo 2:1 (Gambar 1), jarak antar tanaman $25 \mathrm{~cm}$, jarak antar barisan $25 \mathrm{~cm}$, dan jarak antar bedengan $50 \mathrm{~cm}$. Sedangkan perlakuan yang dilakukan antara lain :

1. Persemaian kering dengan perendaman benih menggunakan Bacillus

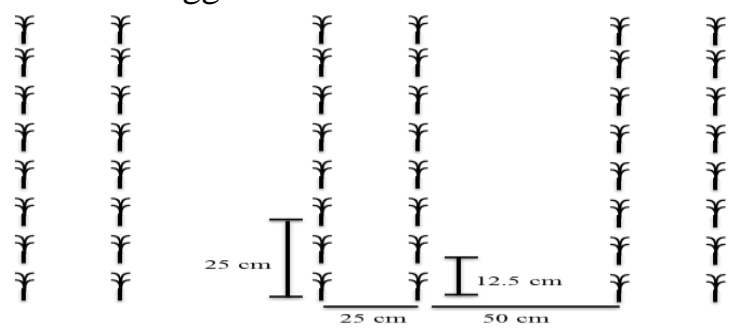

Gambar 1. Prinsip Tanam Jajar Legowo 2:1

2. Pemupukan dengan pupuk kimia, organik dan hayati.

3. Pemeliharaan antara lain

1) Penyulaman : dilakukan sampai 14 hari setelah tanam

2) Penyiangan : sesuai dengan kebutuhan (2-3 kali)

4. Pengendalian Organisme Pengganggu Tanaman (OPT) menggunakan pestisida berdasarkan ambang pengendalian

5. Desain Petak (Gambar 2)

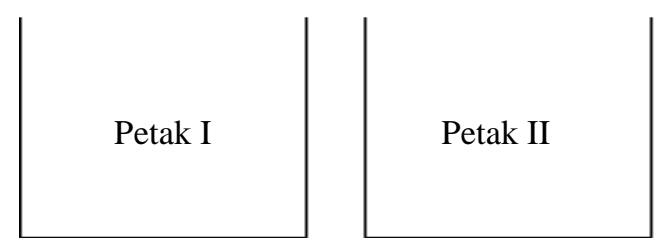

Gambar 2. Pembagian Petak Uji Teknologi Komoditas Padi

HASIL DAN PEMBAHASAN 
Agus Dwi Nugroho, Charisma Ummu F, Ria Puji A, Lendy Vinte I, Ceria Lestari, Setiya Tri P, Novi Anjarwati, Andri Anjarwati, Ely Wisnu B, Dika Afif Prata

Pelaksanaan Program Upaya Khusus (UPSUS) Swasembada Pangan Berkelanjutan

Di Kabupaten Kendal Provinsi Jawa Tengah

Pendampingan Pengawasan Kegiatan

Rehabilitasi Jaringan Irigasi Tersier (RJIT)

Pengelolaan jaringan irigasi yang baik perlu memperhatikan 3 faktor yaitu fisik dan non fisik disertai konsistensi penerapan peraturan perundangan terutama pola dan tata tanam yang telah disepakati bersama yang saling berhubungan dan saling mendukung (Nurrochmad, 2007). Hal ini merupakan dasar bagi pemerintah untuk memperbaiki jaringan irigasi yang ada dengan harapan dapat meningkatkan produksi pangan nasional.

Kegiatan yang bersumber dari APBN ini bertujuan membangun atau merehabilitasi jaringan irigasi di areal persawahan yang kondisinya belum permanen yaitu saluran belum memiliki bangunan irigasi atau masih berupa tanah. Secara umum pelaksanaan RJIT tiap wilayah memiliki kondisi yang berbedabeda. Kecamatan Boja mendapatkan bantuan RJIT untuk 3 desa yaitu Desa Pasigitan, Desa Ngabean dan Desa Kliris. Pelaksanaan RJIT diawali dengan pengajuan proposal dari Perkumpulan Petani Pemakai/Pengguna Air (P3A) melalui penyuluh lapangan yang kemudian diserahkan kepada DP3K. Setelah proposal disetujui, maka kelompok secara resmi mendapatkan bantuan sebesar Rp 80 juta yang digunakan untuk pembelian material dan pembayaran tenaga kerja.

Tabel 1. Kegiatan RJIT Kecamatan Boja

\begin{tabular}{|c|c|c|c|}
\hline \multicolumn{4}{|c|}{ Tahun 2016} \\
\hline No & $\begin{array}{c}\text { Kelompok } \\
\text { Tani }\end{array}$ & $\begin{array}{l}\text { Lokasi } \\
\text { (Desa) }\end{array}$ & Ketua \\
\hline 1 & $\begin{array}{l}\text { Sekar } \\
\text { Makmur }\end{array}$ & Pasigitan & Tukimin \\
\hline 2 & Margo Mulyo & Ngabean & Sumaryono \\
\hline 3 & Karya Utama & Kliris & Atigun \\
\hline
\end{tabular}

Sumber : BPP Kecamatan Boja

Kegiatan RJIT di Kecamatan Boja sampai pada tahap pembuatan rekening penerimaan dana dan survei lokasi RJIT sedangkan rancangan bangunan belum dilaksanakan pada saat aktivitas pendampingan. Hal ini disebabkan penyuluh lapangan dan petani di Kecamatan Boja belum menemukan ahli yang dapat merancang desain jaringan irigasi serta dana dari pemerintah yang belum diterima kelompok.

Wilayah Kecamatan Limbangan memiliki topografi berbukit sehingga jarang terdapat jaringan irigasi tersier. Pada tahun 2016, ada 3 kelompok tani yang mendapat bantuan RJIT namun belum terlaksana karena masih dalam proses pengajuan dana dan rancangan yang belum selesai.

Tabel 2. Kegiatan RJIT Kecamatan Limbangan Tahun 2016

\begin{tabular}{cll}
\hline No & \multicolumn{1}{c}{ Kelompok Tani } & \multicolumn{1}{c}{ Desa } \\
\hline 1 & Harapan Mulya & Gondang \\
2 & Margo Widodo & Tabet \\
3 & Sumber Waras & Margo Sari \\
\hline
\end{tabular}

Sumber : BPP Kecamatan Limbangan

Kegiatan RJIT di Desa Gondang mengusulkan pendanaan untuk irigasi 60 ha. Selama ini pengairan disalurkan lewat irigasi sederhana sehingga air tidak mengalir sempurna. Untuk Desa Tabet, RJIT dalam tahap merancang gambar saluran irigasi untuk pengairan 60 ha sawah. Sedangkan untuk Desa Margo Sari, masih dalam tahap penyelesaian rancang gambar saluran irigasi seluas 60 ha.

Program RJIT Kecamatan Patean dilaksanakan di dua desa yakni Desa Pagersari dan Desa Wirosari. Program ini melibatkan P3A yang didampingi penyuluh pertanian, babinsa (TNI), perangkat desa dan tim pendamping mahasiswa. Luas lahan yang direncanakan akan dialiri jaringan tersier pada masing-masing desa adalah 50 ha dengan bantuan sosial sebanyak Rp 1 juta/ha. Sebelum masa pencairan dana tersebut, kelompok P3A 
Agus Dwi Nugroho, Charisma Ummu F, Ria Puji A, Lendy Vinte I, Ceria Lestari, Setiya Tri P, Novi Anjarwati, Andri Anjarwati, Ely Wisnu B, Dika Afif Prata

Pelaksanaan Program Upaya Khusus (UPSUS) Swasembada Pangan Berkelanjutan Di Kabupaten Kendal Provinsi Jawa Tengah

sudah membeli material baik dibayar tunai maupun hutang.

Tabel 3. Kegiatan RJIT Kecamatan Patean Tahun 2016

\begin{tabular}{cll}
\hline No & \multicolumn{1}{c}{ Kelompok Tani } & \multicolumn{1}{c}{ Desa } \\
\hline 1 & P3A Margo Tertosari & Pagersari \\
2 & P3A Ngudi Raharjo & Wirosari \\
\hline
\end{tabular}

Sumber : BPP Kecamatan Patean

Pada tahun 2016, Kecamatan Sukorejo belum ada kegiatan RJIT. Kegiatan RJIT Kecamatan Sukorejo dilaksanakan pada tahun 2015 yakni di Desa Trimulyo dengan panjang rehabilitasi irigasi 415 meter untuk mengairi lahan 48 ha. Masalah utama terkait pengairan adalah pasokan air yang kurang pada musim kemarau, terutama wilayah di dataran tinggi, sehingga diperlukan bantuan pompa air dan embung.

Pada prinsipnya kegiatan pendampingan pengawasan RJIT oleh tim UGM mampu memberikan laporan bagi dinas bahwa pelaksanaan program dari pemerintah pusat ini masih ada yang belum terlaksana dengan baik sehingga dinas perlu melakukan langkah perbaikan dengan mendampingi kelompok tani dan penyuluh lapangan atau mengirimkan ahli teknik sipil untuk membuat rancangan jaringan irigasi secara tepat.

\section{Pendampingan Pengawasan Penyaluran Bantuan Benih Bersubsidi}

Bantuan benih bersubsidi merupakan upaya pemerintah menyediakan benih berkualitas dengan harga murah sehingga pendapatan petani meningkat. Bantuan benih bersubsidi diberikan kepada kelompok tani yang mengajukan bantuan. Besaran bantuan adalah $25 \mathrm{~kg}$ per hektar. Harga jual benih bersubsidi adalah $\mathrm{Rp} 2.500 / \mathrm{kg}$ sedangkan harga benih pada umumnya di pasaran Rp $10.000 / \mathrm{kg}$. Penyaluran benih telah berjalan lancar dimana bantuan diturunkan di BPP kemudian akan diangkut ke wilayah masingmasing.

Tabel 4. Kelompok Tani Penerima Program Bantuan Benih Bersubsidi di Kecamatan Boja Tahun 2016

\begin{tabular}{|c|c|c|c|}
\hline No & $\begin{array}{l}\text { Kelompok } \\
\text { Tani }\end{array}$ & Desa & $\begin{array}{c}\begin{array}{c}\text { Jumlah } \\
\text { Bantuan } \\
(\mathrm{kg})\end{array} \\
\end{array}$ \\
\hline 1 & Rukun Tani I & Bebengan & 625 \\
\hline 2 & Tani Sari I & Blimbing & 625 \\
\hline 3 & $\begin{array}{l}\text { Gading } \\
\text { Kencana }\end{array}$ & Kaligading & 625 \\
\hline 4 & $\begin{array}{l}\text { Tani } \\
\text { Manunggal }\end{array}$ & Pasigitan & 625 \\
\hline 5 & $\begin{array}{l}\text { Purwogondo } \\
\text { I }\end{array}$ & Purwogondo & 625 \\
\hline 6 & $\begin{array}{l}\text { Ngudi } \\
\text { Makmur }\end{array}$ & Purwogondo & 625 \\
\hline 7 & $\begin{array}{l}\text { Suka } \\
\text { Makmur II }\end{array}$ & Campurejo & 625 \\
\hline 8 & $\begin{array}{l}\text { Suka } \\
\text { Makmur III }\end{array}$ & Banjarejo & 625 \\
\hline
\end{tabular}

Sumber : Data UPTD V Kabupaten Kendal

Penyediaan benih unggul bersubsidi 2016 Kecamatan Sukorejo di Desa Tamping Winarno (Kelompok Tani Ngudi Rahayu) dan Selokaton (Kelompok Tani Sido Rukun) dimana setiap kelompok memperoleh $625 \mathrm{~kg}$ untuk luasan lahan 25 ha. Jenis benih yang dibagikan adalah Varietas Ciherang dan Situbagendit. Kegiatan pendampingan pengawasan penyaluran bantuan benih bersubsidi dari tim UGM menunjukkan bantuan benih telah diterima oleh petani serta sesuai dengan data pengajuan atau dengan kata lain realisasi penyaluran benih bersubsidi oleh pemerintah Kabupaten Kendal telah sesuai dengan yang ditargetkan. 
Agus Dwi Nugroho, Charisma Ummu F, Ria Puji A, Lendy Vinte I, Ceria Lestari, Setiya Tri P, Novi Anjarwati, Andri Anjarwati, Ely Wisnu B, Dika Afif Prata

Pelaksanaan Program Upaya Khusus (UPSUS) Swasembada Pangan Berkelanjutan Di Kabupaten Kendal Provinsi Jawa Tengah

\section{Pendampingan Pola Tanam Jajar Legowo}

Program ini dilakukan dengan rekayasa teknologi untuk mendapatkan populasi tanaman yang optimum serta menambah kelancaran sirkulasi sinar matahari dan udara di sekitar tanaman. Hasil penelitian (Ikhwani, et al., 2013), cara tanam jajar legowo berpeluang menghasilkan gabah lebih tinggi dibandingkan dengan cara tanam tegel. Namun, cara tanam jajar legowo secara sosial kurang disenangi petani karena menggunakan benih dan tenaga kerja lebih banyak, namun mudah dalam perawatan tanaman.

Program jajar legowo di Kecamatan Boja dilaksanakan dengan pola 2:1 sehingga populasi tanaman per hektar meningkat $30 \%$. Jumlah kelompok tani yang mendapatkan bantuan jajar legowo ada 8 kelompok tani dengan bantuan berupa benih padi jenis Ciherang sebesar 25 kilogram per hektar dan caplak.

Secara umum program jajar legowo di Kecamatan Boja berjalan cukup lancar walaupun ada juga kelompok yang belum menerapkan sistem jajar legowo karena kesulitan mencari regu tanam yang bersedia melaksanakan pola tanam jajar legowo. Hambatan lain adalah biaya untuk penanaman lebih mahal karena membutuhkan lebih banyak tenaga kerja.
Tabel 5. Kelompok Tani Penerima Program Jajar Legowo di Kecamatan Boja Tahun 2016

\begin{tabular}{cllcc}
\hline No & $\begin{array}{l}\text { Kelompok } \\
\text { Tani }\end{array}$ & \multicolumn{1}{c}{ Desa } & $\begin{array}{c}\text { Luas } \\
\text { Lahan } \\
\text { (ha) }\end{array}$ & $\begin{array}{c}\text { Jumlah } \\
\text { Bantuan } \\
\text { Benih } \\
\text { (kg) }\end{array}$ \\
\hline 1 & $\begin{array}{l}\text { Dewi Sri } \\
\text { Makmur }\end{array}$ & Blimbing & 25 & 625 \\
2 & $\begin{array}{l}\text { Rejo } \\
\text { Makmur }\end{array}$ & Bebengan & 25 & 625 \\
3 & Wismatani & Purwogondo & 25 & 625 \\
4 & Bina & Medono & 25 & 625 \\
& $\begin{array}{l}\text { Karya Tan } \\
\text { II }\end{array}$ & & \\
5 & $\begin{array}{l}\text { Sidodadi I } \\
6\end{array}$ & Leban & 25 & 625 \\
7 & $\begin{array}{l}\text { Bakti } \\
\text { Suka Tani }\end{array}$ & Meteseh & 25 & 625 \\
8 & $\begin{array}{l}\text { I } \\
\text { Suka }\end{array}$ & Campurejo & 25 & 625 \\
\hline Makmur I & & & \\
\hline
\end{tabular}

Sumber : Data UPTD V

Aktivitas jajar legowo di Kecamatan Limbangan tahun 2016 dilaksanakan di 10 desa dengan bantuan benih varietas Situ Bagendit sebanyak $25 \mathrm{~kg}$ per ha untuk musim tanam April-Mei 2016. Pelaksanaan di Desa Paron, Desa Limbangan dan Desa Sriwulan dengan pola tanam jajar legowo 2:1 dan penanaman dilakukan pada bulan April 2016. Untuk Desa Sumberrahayu dan Desa Tambah Sari dengan pola tanam jajar legowo 2:1 dan penanaman dilakukan pada bulan Mei 2016. 
Agus Dwi Nugroho, Charisma Ummu F, Ria Puji A, Lendy Vinte I, Ceria Lestari, Setiya Tri P, Novi Anjarwati, Andri Anjarwati, Ely Wisnu B, Dika Afif Prata

Pelaksanaan Program Upaya Khusus (UPSUS) Swasembada Pangan Berkelanjutan Di Kabupaten Kendal Provinsi Jawa Tengah

\begin{tabular}{|c|c|c|c|c|}
\hline No & $\begin{array}{c}\text { Kelompok } \\
\text { Tani }\end{array}$ & Desa & $\begin{array}{c}\text { Luas } \\
\text { Lahan } \\
\text { (ha) }\end{array}$ & $\begin{array}{c}\text { Jumlah } \\
\text { Bantuan } \\
\text { Benih } \\
(\mathrm{kg})\end{array}$ \\
\hline 1 & $\begin{array}{l}\text { Tunas } \\
\text { Harapan }\end{array}$ & Peron & 25 & 625 \\
\hline 2 & $\begin{array}{l}\text { Mustika } \\
\text { Karya II }\end{array}$ & Sumberrahayu & 25 & 625 \\
\hline 3 & $\begin{array}{l}\text { Panuntun } \\
\text { Tani }\end{array}$ & Tambahsan & 25 & 625 \\
\hline 4 & $\begin{array}{l}\text { Ngudi } \\
\text { Rahayu }\end{array}$ & Limbangan & 25 & 625 \\
\hline 5 & $\begin{array}{l}\text { Ngudi } \\
\text { Rahayu }\end{array}$ & Sriwulan & 25 & 625 \\
\hline 6 & Sidodadi I & Ngesrepbalong & 25 & 625 \\
\hline 7 & $\begin{array}{l}\text { Candirejo } \\
\text { III }\end{array}$ & Gonoharjo & 25 & 625 \\
\hline 8 & $\begin{array}{l}\text { Sido } \\
\text { Utomo }\end{array}$ & Jawisari & 25 & 625 \\
\hline 9 & Lestari & Tamanrejo & 25 & 625 \\
\hline 10 & $\begin{array}{l}\text { Ngudi } \\
\text { Raharjo } \\
\text { III }\end{array}$ & Pagerwojo & 25 & 625 \\
\hline
\end{tabular}

Sumber : DP3K Kecamatan Limbangan (2016)

Aktivitas penanaman jajar legowo di Kecamatan Kangkung dilaksanakan di Desa Kalirejo, Rejosari dan Sendang Kulon. Setiap desa tersebut mendapat bantuan benih padi Situbagendit sebanyak $625 \mathrm{~kg}$ untuk lahan luasan 25 ha.

Sistem tanam jajar legowo sudah mulai diterapkan beberapa kelompok tani di Kecamatan Patean terutama di empat desa yakni Desa Curugsewu, Sidodadi, Kalices dan Sidokumpul. Kelompok tani yang bersedia menerapkan sistem tanam jajar legowo akan memperoleh bantuan benih per kelompok tani sebesar $625 \mathrm{~kg}$ untuk luasan 25 hektar.

\section{Penguatan Kelembagaan Kelompok}

Kegiatan utama penguatan kelembagaan kelompok dilaksanakan melalui pertemuan kelompok tani untuk membahas budidaya tanaman, simpan pinjam dan aktivitas lainnya berupa penyuluhan untuk mendorong kelompok tani berbadan hokum serta berbagai pelatihan. Pertemuan kelompok tani di Kecamatan Kangkung salah satunya dilaksanakan di BPP kecamatan dengan peserta sebanyak 50 orang yang merupakan petani di Desa Laban dan Desa Kangkung. Materi yang diberikan antara lain pembuatan dan pengaturan administrasi kelompok, pengenalan dan cara pengendalian OPT. Penguatan kelembagaan lainnya di Kecamatan Kangkung adalah pembuatan pupuk dan pestisida organik di kelompok tani Sumber Mulyo Desa Tanjungmojo. Bahan untuk pembuatan pupuk organik berasal dari kangkung $(\mathrm{N})$, akar bambu (P), dan bonggol pisang $(\mathrm{K})$ serta EM4. Bahan yang diperlukan untuk pembuatan fungisida jamur Trichoderma yaitu air kelapa, air rendaman kedelai, indukan jamur Trichoderma, dan tetes tebu. Aktivitas terakhir dalam penguatan kelembagaan di Kecamatan Kangkung adalah Sekolah Lapang Pengendalian Hama Terpadu jagung pada gapoktan di Desa Tanjungmojo. Kegiatan dilaksanakan 10 kali pertemuan setiap seminggu dengan jumlah peserta kegiatan sebanyak 30 orang per pertemuan. SLPHT dilaksanakan dengan pemandu POPT dan koordinator penyuluh BPP kecamatan. Kegiatan ini juga dilengkapi tes sebelum dan setelah pelaksanaan SLPHT. Berdasarkan posttest diperoleh hasil bahwa terdapat peningkatan pengetahuan oleh petani dalam pengendalian Organisme Pengganggu Tanaman.

Penyuluhan juga dilakukan tim UGM di Kecamatan Limbangan tentang pertanian organik (Gambar 5). Dari kegiatan ini, petani memperoleh wawasan mengenai tata cara bertani secara organik dan keunggulannya serta cara sertifikasi organik. Petani juga mulai mengimplementasikan budidaya padi, walaupun masih semi organik yakni menggabungkan penggunaan pupuk organik dengan pupuk kimia. Menurut Mayrowani 
Agus Dwi Nugroho, Charisma Ummu F, Ria Puji A, Lendy Vinte I, Ceria Lestari, Setiya Tri P, Novi Anjarwati, Andri Anjarwati, Ely Wisnu B, Dika Afif Prata

Pelaksanaan Program Upaya Khusus (UPSUS) Swasembada Pangan Berkelanjutan

Di Kabupaten Kendal Provinsi Jawa Tengah

(2012), walaupun pemerintah telah mencanangkan berbagai kebijakan dalam pengembangan pertanian organik seperti 'Go Organic 2010', namun perkembangan pertanian organik di Indonesia masih sangat lambat. Keadaan ini disebabkan kendala pasar, rendahnya minat konsumen dan pemahaman terhadap produk organik, dan proses sertifikasi yang dianggap berat oleh petani kecil. Berdasrkan hasil penelitian Rubiyanti, Priyanto, \& Maria, (2010), diperoleh bahwa lahan pertanian organik memiliki tingkat kesuburan tanah dan keuntungan lebih baik dibandingkan pertanian anorganik, walaupun besarnya investasi lahan pertanian organik pada awalnya juga lebih tinggi dibandingkan lahan anorganik.

Pelatihan yang dilakukan tim UGM antara lain pelatihan perbanyakan mikoriza dan pembuatan biochar. Mikoriza merupakan fungi yang menginfeksi akar tanaman dan mampu meningkatkan efisiensinya dalam serapan pupuk. Hasil gabah akan lebih tinggi pada tanah tidak steril dengan inokulasi mikoriza daripada tanah tanah steril. Pemberian pupuk hayati seperti mikoriza perlu diintensifkan untuk meningkatkan produktivitas dan keberlanjutan pertanian di lahan padi gogo (Syamsiyah et al., 2014). Perbanyakan mikoriza dilakukan dengan cara :

1. Tanah dimasukkan dalam pot dan ditambahkan pasir,

2. Disiapkan 5-10 lubang dimana setiap lubang diisi $1 / 2$ sendok teh mikoriza dan 1 biji jagung,

3. Dilakukan penyiraman dan pemupukan (selain pupuk phospat).

4. Apabila jagung telah berbunga maka penyiraman dihentikan,

5. Tanaman jagung kemudian dipotong dan akar dicacah kemudian tanah dikeringkan dan digunakan untuk menginfeksi tanaman lain.
Hasil dari pelatihan ini adalah petani memperoleh pengetahuan tentang manfaat mikoriza dan cara pembuatannya. Bahkan, petani kemudian mengaplikasikan mikoriza di lahan pertaniannya beberapa hari setelah pelatihan.

Pelatihan pembuatan biochar merupakan pelatihan untuk pembuatan pupuk organik dengan memanfaatkan sumber daya lokal. Pembuatan pupuk organik pertama adalah dengan memanfaatkan sampah organik rumah tangga yang kemudian dimasukkan dalam tong. Proses penguraian sampah dengan memanfaatkan lalat hitam (Hermetia illucens) dan lama-kelamaan akan dihasilkan pupuk cair yang dapat dimanfaatkan oleh petani. Jenis pupuk organik kedua adalah dengan membakar kayu yang kemudian didinginkan sehingga terbentuk arang kayu. Arang kayu ini dapat dimanfaatkan sebagai pupuk dengan cara disebar ke lahan pertanian. Hasil dari pelatihan ini adalah memberikan pengetahuan bagi petani untuk memanfaatkan limbah organik rumah tangga dan lingkungan untuk diolah menjadi pupuk dan diaplikasikan pada lahan pertanian

Kegiatan penyuluhan dan pelatihan mampu memberikan pengetahuan bagi petani tentang budidaya pertanian organik serta pemanfaatan limbah rumah tangga untuk diolah menjadi pupuk. Kegiatan penyuluhan dan pelatihan ini juga akan mengubah pola budidaya petani sehingga mampu mengurangi ketergantungan pada penggunaan pupuk kimia.

\section{Uji Teknologi/Demplot}

Uji teknologi dilakukan di Desa Meteseh Kecamatan Boja (Gambar 8). Pemilihan lokasi berdasarkan kesepakatan antara tim UGM dengan DP3K Kabupaten Kendal dimana aktivitas kegiatan 
Agus Dwi Nugroho, Charisma Ummu F, Ria Puji A, Lendy Vinte I, Ceria Lestari, Setiya Tri P, Novi Anjarwati, Andri Anjarwati, Ely Wisnu B, Dika Afif Prata

Pelaksanaan Program Upaya Khusus (UPSUS) Swasembada Pangan Berkelanjutan

Di Kabupaten Kendal Provinsi Jawa Tengah

pendampingan dan uji teknologi di Desa Meteseh masih sedikit. Uji teknologi yang diterapkan tim UGM antara lain :

1. Penggunaan pupuk hayati Bacillus plus untuk perendaman benih dan aplikasi di lapangan yang berfungsi memperkuat perakaran dan daya tahan tanaman terhadap serangan organisme pengganggu tanaman (Mukamto et al., 2015),

2. Penggunaan pupuk berimbang yakni menggabungkan pupuk kimia dan pupuk organik,

3. Sistem tanam jajar legowo $2: 1$,

4. Pengendalian OPT ramah lingkungan.

Hasil uji teknologi pertanian UGM adalah padi dengan hasil panen 5,5 ton/ha atau lebih tinggi daripada rata-rata hasil panen di Desa Meteseh yakni 4,5 ton/ha. Selain itu, tim UGM juga mampu memberikan wawasan bagi petani mengenai hasil sistem budidaya tanaman jajar legowo yang lebih tinggi dari sistem tanam biasa. Hal ini akan mengubah persepsi petani bahwa populasi padi yang sedikit pada sistem jajar legowo belum tentu menghasilkan produksi gabah yang sedikit pula.

Aktivitas uji teknologi selain dilakukan oleh UGM juga dilaksanakan oleh Balai Penyuluhan Kecamatan Kangkung. Uji teknologi dilaksanakan di Desa Sukodadi untuk varietas kedelai Grobogan, Argomulyo dan Dena 1. Varietas tersebut ditanam dengan jarak tanam $40 \mathrm{~cm}$ x $15 \mathrm{~cm}$. Penanaman dilakukan pada lahan yang sebelumnya belum pernah ditanami kedelai. Dari ketiga varietas yang diujicobakan, varietas Dena 1 memiliki pertumbuhan paling cepat dan tanamannya lebih tinggi dari dua varietas lain. Untuk daya hasil varietas Grobogan paling tinggi karena ukuran biji yang besar.

Uji teknologi juga dilaksanakan di Desa Ngadiwarno Kecamatan Sukorejo untuk demplot padi varietas Ciherang dengan sistem jajar legowo 2:1 dan 4:1. Penanaman dilaksanakan oleh PPL bersama petani dan mahasiswa pendamping. Permasalahan yang terjadi pada demplot ini adalah serangan ulat dan hama walang sangit sehingga produksi demplot rendah.

Masalah utama dalam pendampingan UPSUS di Kendal yakni waktu pendampingan yang terlalu pendek sehingga belum mampu sepenuhnya mengatasi masalah petani. Hasil ini juga sesuai dengan pelaksanaan UPSUS di Wonosobo yang juga waktu pendampingan yang pendek dan membuat pendampingan kurang optimal (Nugroho, et al., 2017).

\section{SIMPULAN}

Hasil pendampingan pengawasan program UPSUS menunjukkan kegiatan Rehabilitasi Jaringan Irigasi Tersier (RJIT) ada yang belum terlaksana, kegiatan bantuan benih bersubsidi telah terealisasi sesuai target, kegiatan tanam jajar legowo berjalan dengan baik. Aktvitas UPSUS akan memberikan pengetahun baru bagi petani tentang teknologi usahatani serta akan berdampak pada peningkatan produksi dan pendapatan petani. Beberapa masalah yang dihadapi dalam pelaksanaan UPSUS antara lain waktu pendampingan yang terlalu pendek sehingga belum mampu sepenuhnya mengatasi masalah petani serta pelaksanaan RJIT ada yang terlambat karena kelompok tani belum memperoleh dana dari pemerintah. Dalam rangka pengembangan UPSUS, sebaiknya waktu pendampingan dapat diperpanjang serta dinas juga perlu melakukan pengawasan agar program seperti RJIT dapat dilaksanakan tepat waktu 
Agus Dwi Nugroho, Charisma Ummu F, Ria Puji A, Lendy Vinte I, Ceria Lestari, Setiya Tri P, Novi Anjarwati, Andri Anjarwati, Ely Wisnu B, Dika Afif Prata

Pelaksanaan Program Upaya Khusus (UPSUS) Swasembada Pangan Berkelanjutan Di Kabupaten Kendal Provinsi Jawa Tengah

\section{DAFTAR PUSTAKA}

Badan Pusat Statistik. (2013). Laporan Hasil Sensus Pertanian 2013. Jakarta : BPS

Darwanto. (2010). Analisis Efisiensi Usahatani Padi di Jawa Tengah (Penerapan Analisis Frontier). Jurnal Organisasi Dan Manajemen, 6(1), 4657.

Ikhwani, Pratiwi, G. R., Paturrohman, E., \& Makarim, A. K. (2013). Peningkatan Produktivitas Padi Melalui Penerapan Jarak Tanam Jajar Legowo. Jurnal IPTEK Tanaman Pangan, 8(2), 72-79.

Kementertian Pertanian. (2015). Modul Pendampingan Mahasiswa Dalam Rangka Upaya Khusus Peningkatan Produksi Padi, Jagung dan Kedelai. Jakarta : Kementerian Pertanian.

Mayrowani, H. (2012). Pengembangan Pertanian Organik di Indonesia The Development Of Organic Agriculture In Indonesia. Forum Penelitian Agro Ekonomi, 30(2), 91-108.

Mukamto, Ulfah, S., Mahalina, W., Syauqi, A., Istiqfaroh, L., \& Trimulyono, G. (2015). Isolasi dan Karakterisasi Bacillus sp. Pelarut Fosfat dari Rhizosfer Tanaman Leguminosae. Sains Dan Matematika, 3(2), 62-68.

Syamsiyah., Sunarminto, J. B. H., Hanudin, E., \& Widada, J. Pengaruh Inokulasi Jamur Mikoriza Arbuskula Terhadap Glomalin, Pertumbuhan dan Hasil Padi. Sains Tanah - Jurnal Ilmu Tanah dan Agroklimatologi, 11(1), 39-46.

Nugroho, A. D., Utami, S. N. H., Yuslianti, Y., Nurrokhmah, L., Huda, M. A. A., Suryani. L., Riyadi, L., Ulfaizah., Septijono, T., \& Adhini, H. A. N. (2017). Pelaksanaan Program Upaya Khusus
(UPSUS) Swasembada Pangan di Kabupaten Wonosobo Provinsi Jawa Tengah. Jurnal Pengabdian Kepada Masyarakat, 3(1), 1-17.

Nurrochmad, F. (2007). Analisis Kinerja Jaringan Irigasi. Agritech. 27(4), 182190.

Rubiyanti, Priyanto, S.H., \& Maria. (2010). Analisis Nilai Ekonomi Penggunaan Lahan Pertanian Organik dan Anorganik (Studi Kasus Komparatif : Megamendung, Kabupaten Bogor). Prosiding Seminar Nasional Pertanian Organik. 